\title{
PENGELOLAAN PAUD BERBASIS EXPERIENTIAL LEARNING
}

\author{
Alim Harun Pamungkas ${ }^{1,2}$, Vevi Sunarti ${ }^{1}$ \\ ${ }_{1}^{1}$ Jurusan Pendidikan Luar Sekolah Fakultas Ilmu Pendidikan Universitas Negeri Padang \\ ${ }^{2}$ Email: alimharun@fip.unp.ac.id
}

\begin{abstract}
PAUD institutions are often interpreted as a place of learning for children who are only oriented to the skills and knowledge of reading, writing, counting, and drawing. PAUD institutions should focus on children's development related to religious and moral, physical, cognitive, language, social, emotional and artistic aspects. Thus the educational services provided by PAUD institutions must be able to facilitate all aspects of child development through enjoyable learning activities and help increase understanding of parents or the surrounding community about playing as a fun learning activity. Fun learning activities for early childhood need to be designed to help children get real life simulations in their daily activities. PAUD institution learning activities need to be adjusted to the stages of child development based on experiential learning model learning principles. On that basis, an activity is needed that facilitates the creation of learning experiences for managers and parents or community members in PAUD institutions about experiential learning.
\end{abstract}

Keywords: Childhood Education (PAUD), Experiential Learning

\section{PENDAHULUAN}

Masa kanak-kanak merupakan fase penting bagi perkembangan anak-anak. Pada fase ini, orang tua dan fasilitator belajar anak perlu untuk membebaskan anak dalam mengenal dan belajar sesuatu (Ismaniar \& Sunarti, 2018; Senowarsito, Nugrahani, \& D, 2012). Proses pengenalan atau pembelajaran anak tersebut, dapat dilakukan melalui kegiatan bermain. Bermain sangat penting untuk proses tumbuh kembang anak. Bermain merupakan pembelajaran yang efektif untuk anak-anak. Bermain dapat membantu berkembangnya beragam dari potensi yang dimiliki anak-anak. Potensi anak-anak untuk mengeksplorasi, menemukan dan memanfaat sesuatu yang ada di sekitar dapat dilakukan oleh dengan bermain (Holis, 2016; Khobir, 2009).

Pengalaman anak-anak dalam kegiatannya sehari-hari merupakan dasar bagi anakanak untuk belajar berpikir. Pengalaman yang diperoleh anak-anak setidaknya diperoleh dari enam sumber, berikut: (1) pengalaman sensorik; (2) pengalaman berbahasa; (3) latar belakang budaya; (4) teman sebaya atau teman sepermainan; (5) media masa; dan (6) kegiatan kelilmuan (scientific activities). Namun demikian, sesuai dengan prinsip keunikan yang terdapat pada setiap diri anak-anak, maka tidak ada seorang pun anak yang memiliki kesamaan dengan anak lainnya (Moore, Boyd, \& Dooley, 2010). 
Keunikan pada diri anak-anak termasuk pada gaya anak-anak dalam belajar. Gaya belajar anak-anak dipengaruhi oleh sebab alamiah (nature) dan lingkungan bentukan (nurture). Agar kegiatan belajar yang dilakukan anak-anak lebih efektif dan orang tua dapat membantu proses berkembangnya bakat dan prestasi anak, maka penting bagi setiap orang tua dan fasilitator belajar anak untuk memahami gaya belajar dari setiap anak dan model pembelajaran yang sesuai dengan perkembangan anak.

Salah satu model pembelajaran yang dapat digunakan dalam pembelajaran anak-anak di usia dini adalah pembelajaran berbasis pengalaman (experiential learning). Experiential learning adalah belajar melalui pengalaman langsung yang disajikan melalui kegiatan bermain, simulasi, dan petualangan sebagai media penyampaian materi (D. A. Kolb, 2014). Artinya, melalui kegiatan bermain, anak-anak dapat secara aktif terlibat dalam seluruh kegiatan pembelajaran yang dilakukan (Sharlanova, 2004).

Model experiential learning ini diharapkan dapat menjadi jalan keluar bagi kesalahpahaman yang sering terjadi pada pendidikan anak usia dini, yaitu pemahaman bahwa kegiatan belajar adalah suatu kegiatan yang terpisah dari kegiatan bermain anak. Padahal sejatinya, bagi anak-anak bermain dan belajar adalah dua kegiatan yang sama-sama berkontribusi terhadap proses tumbuh kembang.

\section{EXPERIENTIAL LEARNING SEBAGAI MODEL PEMBELAJARAN}

Pembelajaran dengan model experiential learning mulai diperkenalkan pada tahun 1984 oleh David Kolb dalam bukunya yang berjudul "Experiential learning: Experience as the Source of Learning and Development". Menurut Kolb (2014) experiential learning adalah proses bagaimana pengetahuan diciptakan melalui perubahan bentuk pengalaman. Pengetahuan diakibatkan oleh kombinasi pemahaman dan mentransformasikan pengalaman. Lebih lanjut, Sharlanova (2004) mendefinisikan experiential learning sebagai proses belajar, proses perubahan yang menggunakan pengalaman sebagai media belajar atau pembelajaran. Experiential learning mencakup keterkaitan antara berbuat dan berpikir. Jika siswa terlibat aktif dalam proses belajar, maka siswa itu akan belajar jauh lebih baik. Hal ini dikarenakan dalam proses belajar tersebut siswa secara aktif berpikir tentang apa yang dipelajari dan kemudian bagaimana menerapkan apa yang telah dipelajari dalam situasi nyata (A. Y. Kolb \& Kolb, 2008; D. A. Kolb, Boyatzis, \& Mainemelis, 2000).

Lebih lanjut, Mahfudin (dalam Sholihah, Utaya, \& Susilo, 2016) mendefinisikan experiential learning sebagai model pembelajaran yang diharapkan dapat menciptakan proses belajar yang lebih bermakna, dimana murid mengalami apa yang mereka pelajari. Melalui model ini, murid tidak hanya belajar tentang konsep materi belaka karena dalam hal ini murid dilibatkan secara langsung dalam proses pembelajaran untuk dijadikan suatu pengalaman. Di sini mengharuskan pendidik terlibat langsung dalam memotivasi peserta didik dan refleksi difokuskan untuk meningkatkan pengetahuan, mengembangkan keterampilan.

Menurut D. A. Kolb (2014), experiential learning memiliki enam karakteristik, yaitu (1) Belajar terbaik dipahami sebagai suatu proses. Tidak dalam kaitannya dengan hasil yang dicapai; (2) Belajar merupakan proses berkesinambungan yang didasarkan pada pengalaman; (3) Belajar memerlukan resolusi konflik-konflik antara gaya-gaya yang berlawanan dengan cara dialektis; (4) Belajar adalah suatu proses yang holistik; (5) Belajar melibatkan transaksi antara seseorang dengan lingkungan; (6) Belajar adalah proses tentang menciptakan 
pengetahuan yang merupakan hasil dari hubungan antara pengetahuan sosial dan pengetahuan pribadi.

Model pembelajaran experiential learning menekankan pada dua aspek yang saling berkaitan secara dialektik, yaitu grasping experience (memperoleh pengalaman), dan transforming experience (mentransformasi pengalaman). Grasping experience mencakup dua hal, yaitu Concrete Experience atau pengalaman (CE) dan Abstract Conceptualization atau merefleksikan (AC), sedangkan transforming experience juga mencakup du hal, yaitu Reflective Observation atau berpikir (RO) dan Active Experimentation atau bertindak (AE). Pada proses pembelajaran, aspek-aspek ini digambarkan sebagai siklus pembelajaran yang ideal atau spiral di mana pembelajar menyentuh semua basis (D. A. Kolb, 2014). Untuk lebih jelas lihat Gambar 1.

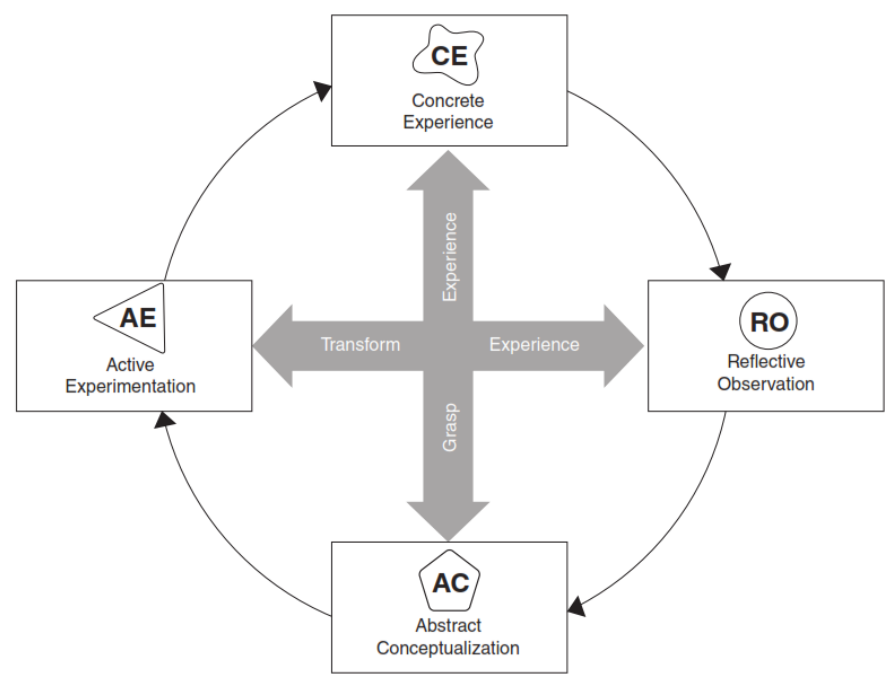

Gambar 4. Model Experiential learning David A. Klob (D. A. Kolb, 2014)

\section{PELAKSANAAN EXPERIENTIAL LEARNING DI PAUD}

\section{Pengalaman Konkret (Concrete Experience)}

Pada tahap ini anak secara individu menekankan pada pembelajaran berpikir terbuka dan kemampuan beradaptasi daripada pendekatan sistematik pada situasi masalah. Pada tahap ini guru PAUD menyediakan stimulus yang mendorong anak untuk melakukan sebuah aktivitas. Aktivitas yang dimaksud adalah aktivitas yang berangkat dari suatu pengalaman yang pernah dialami oleh anak sebelumnya, baik formal maupun informal ataupun situasi yang realistis. Untuk tempat pelaksanaan bisa di dalam ataupun di luar kelas dan dikerjakan oleh pribadi ataupun kelompok.

\section{Pengamatan Reflektif (Reflective Observation)}

Pada tahap ini anak mengamati demonstrasi sederhana serta mencoba mengeluarkan pendapat mengapa dan bagaimana hal tersebut terjadi. Pada tahap ini guru mengajak anak untuk mengamati pengalaman dari aktivitas yang dilakukan oleh anak dengan menggunakan panca indera atau dengan bantuan alat peraga. Selanjutnya, anak diarahkan untuk merefleksikan pengalamannya. Dari hasil refleksi ini anak akan menarik pelajaran. Dalam hal 
ini, proses refleksi akan terjadi bila guru mampu mendorong anak tersebut untuk mendeskripsikan kembali pengalaman yang diperolehnya, mengomunikasikan kembali, dan belajar dari pengalaman tersebut.

\section{Konsepsi Abstrak (Abstrak Conceptualization)}

Tahap ini anak diarahkan untuk mengerti konsep secara umum dengan menggunakan tahap pertama dan kedua sebagai acuan. Konsepsi abstrak mengharuskan anak untuk menggunakan logika dan pikiran untuk memahami situasi dan masalah. Setelah melakukan observasi dan refleksi, maka dalam tahap pembentukan konsep, anak mulai mengonseptualisasi suatu teori atau model dari pengalaman yang diperoleh dan mengintegrasikan dengan pengalaman sebelumnya. Pada fase ini dapat ditentukan apakah terjadi pemahaman baru atau proses belajar pada diri anak atau tidak. Jika terjadi proses belajar, maka 1) anak akan mampu mengungkapkan aturan-aturan umum untuk mendeskripsikan pengalaman tersebut; 2) anak menggunakan teori yang ada untuk menarik kesimpulan terhadap pengalaman yang diperoleh; 3) anak mampu menerapkan teori yang terabstraksi untuk menjelaskan pengalaman tersebut.

\section{Percobaan Aktif (Active Experimentation)}

Pada tahap ini anak diarahkan menggunakan teori yang mereka dapat selama konsepsi abstrak untuk membuat prediksi. Melalui pembelajaran ini, anak diharapkan dapat membangun konsep yang bermakna dan kepercayaan diri dalam memecahkan masalah dan membuat keputusan yang cermat. Pada tahap ini, anak mencoba merencanakan bagaimana menguji keampuhan model atau teori untuk menjelaskan pengalaman baru yang akan diperoleh selanjutnya. Pada tahap aplikasi akan terjadi proses bermakna karena pengalaman yang diperoleh anak sebelumnya dapat diterapkan pada pengalaman atau situasi problematika yang baru. Setiap anak memiliki keunikan sendiri dan tidak pernah ada dua orang anak yang memiliki pengalaman hidup yang sama persis. Dua anak yang tumbuh dalam lingkungan yang sama dan mendapatkan perlakuan yang sama, belum tentu akan memiliki pemahaman, pemikiran dan pandangan yang sama terhadap dunia sekitarnya. Masing-masing memiliki cara pandang sendiri terhadap setiap peristiwa yang dilihat dan dialaminya cara pandang tersebut yang disebut sebagai gaya belajar.

\section{KESIMPULAN}

Model experiential learning menekankan pada sebuah model pembelajaran yang holistik dalam proses belajar. Dalam experiential learning, pengalaman mempunyai peran sentral dalam proses belajar. Penekanan inilah yang membedakannya dari teori-teori belajar lainnya. Istilah "experiential" disini untuk membedakan antara belajar kognitif yang cenderung menekankan kognisi lebih dari pada afektif. Dan teori belajar behavior yang menghilangkan peran pengalaman subjektif dalam proses belajar. Penerapan model ini pada pendidikan anak usia dini diharapkan dapat mengoptimalkan masa perkembangan anak usia dini yang dikenal juga dengan golden age sehingga mampu mengoptimalkan potensinya di kemudian hari. Selanjutnya, experiential learning juga diharapkan mampu menjadi jalan keluar bagi kesalahpahaman yang sering terjadi pada pendidikan anak usia dini, yaitu pemahaman bahwa kegiatan belajar adalah suatu kegiatan yang terpisah dari kegiatan bermain anak. Selanjutnya, juga sebagai model yang bisa menjembatani sinergi lembaga PAUD dan orang tua dalam melaksanakan pendidikan pada anak usia dini. 


\section{DAFTAR RUJUKAN}

Holis, A. (2016). Belajar Melalui Bermain untuk Pengembangan Kreativitas dan Kognitif Anak Usia Dini. Jurnal Pendidikan Universitas Garut, 9(1), 23-37. Retrieved from https: / $/$ www.google.com/url? sa $=$ t\&rct $=$ j\&q $=\&$ esrc $=$ s\&source $=$ web\&cd $=1 \& \mathrm{cad}=$ rja \&uact $=8 \& v e d=2$ hUKEwiM06eMoareAhUUTI8KHW6ZDSEQFjAAegQICRAC\&ur l=https $\% 3 \mathrm{~A} \% 2 \mathrm{~F} \% 2 \mathrm{Fjournal}$.uniga.ac.id $\% 2$ Findex.php $\% 2 \mathrm{FJP} \% 2 \mathrm{Farticle} \% 2 \mathrm{Fdownload}$ $\% 2 \mathrm{~F} 84 \% 2 \mathrm{~F} 86 \& u s g=\mathrm{AOvVaw} 2 \mathrm{ldS} 8$ ufK8IMA7tilmu8C0n

Ismaniar, \& Sunarti, V. (2018). Buku Ajar Pelatihan Parenting. Padang: Penerbit Jurusan Pendidikan Luar Sekolah Fakultas Ilmu Pendidikan Universitas Negeri Padang. Retrieved from https://www.researchgate.net/profile/Ismaniar_Ismaniar/publication/326928635_Bu ku_Ajar_Pelatihan_Parenting/links/5b6d0376299bf14c6d97e2ba/Buku-AjarPelatihan-Parenting.pdf?origin=publication_detail

Khobir, A. (2009). Upaya Mendidik Anak Melalui Permainan Edukatif. FORUM TARBIYAH, 7(2), 195-208. Retrieved from https://media.neliti.com/media/publications/69264-ID-none.pdf

Kolb, A. Y., \& Kolb, D. A. (2008). Experiential Learning Theory: A Dynamic, Holistic Approach to Management Learning, Education and Development. In S. J. Armstrong \& C. Fukami (Eds.), Handbook of Management Learning, Education and Development. London: Sage Publications. Retrieved from https://www.researchgate.net/profile/David_Kolb/publication/267974468_Experient ial_Learning_Theory_A_Dynamic_Holistic_Approach_to_Management_Learning_Ed ucation_and_Development/links/5559122408ae6fd2d826eb12/Experiential-LearningTheory-A-Dynamic-Holistic-Approach-to-Management-Learning-Education-andDevelopment.pdf?origin=publication_detail

Kolb, D. A. (2014). Experiential Learning: Experience as the Source of Learning and Development (2nd ed.). New Jersey: Pearson Education, Inc.

Kolb, D. A., Boyatzis, R. E., \& Mainemelis, C. (2000). Experiential Learning Theory: Previous Research and New Directions. In R. J. Sternberg \& L. F. Zhang (Eds.), Perspectives on Cognitive, Learning, and Thinking Styles. New Jersey: Lawrence Erlbaum. Retrieved from https://www.researchgate.net/profile/David_Kolb/publication/284458870_Experient ial_Learning_Theory_Previous_Research_and_New_Directions_in_in_Perspectives_o n_Thinking_Learning_and_Cognitive_Styles/links/56808cd508ae1975838b0c55/Expe riential-Learning-Theory-Previous-Research-and-New-Directions-in-in-Perspectiveson-Thinking-Learning-and-Cognitive-Styles.pdf?origin=publication_detail

Moore, C., Boyd, B. L., \& Dooley, K. E. (2010). The Effects of Experiential Learning with an Emphasis on Reflective Writing on Deep-Level Processing of Leadership Students. Journal of Leadership Education, 9(1), 36-52. Retrieved from http://www.journalofleadershiped.org/attachments/article/170/JOLE_9_1_Moore_B oyd_Dooley.pdf

Senowarsito, Nugrahani, D., \& D, A. C. (2012). Parenting untuk Anak Usia Dini. E-DIMAS, 3(2), 52-57. https://doi.org/http://dx.doi.org/10.26877/e-dimas.v3i2.1550 
Sharlanova, V. (2004). Experiential Learning. Trakia Journal of Sciences, 2(4), 36-39. Retrieved from http:/ / tru.uni-sz.bg/tsj/Volume2_4/EXPERIENTIAL LEARNING.pdf

Sholihah, M., Utaya, S., \& Susilo, S. (2016). Pengaruh Model Experiential Learning Terhadap Kemampuan Berpikir Siswa SMA. Jurnal Pendidikan: Teori, Penelitian, Dan Pengembangan, 1(11), 2096-2100. Retrieved from http://journal.um.ac.id/index.php/jptpp/article/download/7869/3608 